\title{
The Chapter of Bärdi Bäk khan in the Čingiz-nāmä of Ötämiš Ḥăjȳi Tolu Bay, ämir of the Golden Horde
}

\author{
GÖNCÖL, CSABA*
}

Ottoman Era Research Group, University of Szeged,

Dugonics tér 13, 6720, Szeged, Hungary

Received: December 27, 2018 • Accepted: January 31, 2020

(c) 2021 The Author

\section{ABSTRACT}

In the past few years researchers of the history of the Golden Horde devoted considerable attention to formerly neglected chronicles written in Turkic in the successor states of the Ulus of J̌uči, particularly to the so called Čingiz-nāmä of Ötämiš Hāyjjȳ. Though this collection of genuine oral tradition is an indispensable source, a critical approach is oftentimes overlooked by the scholars using it. This paper aims to demonstrate how the historical consciousness of the populace of the Golden Horde altered the stories behind certain events. For this purpose, the story of Bärdi Bäk khan in the Čingiz-nāmä will be subjected to criticism.

\section{KEYWORDS}

Ötämiš Hāājj̄̄î Čingiz-nāmä, Bärdi Bäk khan, Tolu Bay, historiography of the steppe.

\footnotetext{
* Corresponding author. E-mail: csaba986@gmail.com
} 


\section{INTRODUCTION}

Oral historical tradition of the populace of the Golden Horde, preserved in Turkic chronicles, connected the dissolution of the Batuid line with the actions of Bärdi Bäk khan (1357-1359). These sources usually explain the fratricide of the ruler with his lust for power and unwillingness to share it. One only needs to recall the words of Abu l-Gāzī Bahadur khan (1644-1663), ruler and chronicler of the Khanate of Hīwa: 'He (Bärdi Bäk khan - Cs. G.) speared no one from is older or younger brothers, from his siblings and kin (qarïndaš urug̈inda), because he wanted the country (yurt) forever for himself. He did not know that the word is temporal. In the end his rule did not last two years. In the year 762 (11 November 1360 - 01 November 1361 - Cs. G.) he died. The lineage (äwlād) of Șayïn khan ceased at Bärdi Bäk' (Abu 1-Ġāzī/Desmaisons1970²: 176-177).

However, there is a chronicle from the Khanate of Hiwwa which tells us a different motive for Bärdi Bäk khan’s fratricide. Its writer, Ötämiš Ḥājj̄̄ b. Mävlānā Muḥammad Dōstī, served in the courts of Šaybānid Ilbars khan (c. 1511-1518), and later Iš Muhammad Sulțān, brother of Dōst Muhammad khan (c. 1556-1558). Ötämiš Hājy̌ī was a gatherer of oral traditions circulating on the steppe (qarï söz), with which he became renowned. In the 1550s Iš Muhammad Sulțān summoned him to his court and commissioned him to compile a book on the history of the Jučids. Based on the traditions he collected, Ötämiš Hāy̌ǰi drafted his chronicle, in scholarly literature known as the Čingiz-nāmä 'Book of Genghis' (Ötämiš Hāăǰì/Kawaguchi and Nagamine 2008: $6-8){ }^{1}$

Ötämiš Hăy̌jī was aware that historical consciousness influenced oral traditions and that they change time to time: 'It is [well] known - he writes - that most of the words one hears with ears are lies.' (Ötämiš Hāăjȳi/Kawaguchi and Nagamine 2008: 8). Changes in the tradition of certain events, however, can be an excellent asset to modern historians, given we are able to map these. The aim of this paper is to scrutinize the plot of Bärdi Bäk khan’s story in Ötämiš Hāǎjȳis Čingiz-nāmä and compare its details to the testimony of Russian and Persian sources on the same event. Through a comparison we are able to establish two versions of the same story: a 'how it must have happened' - basically how modern historians evaluate the events - and 'how the people thought it happened' - the version Ötämiš Hājūji transmitted. ${ }^{2}$ The difference between the two may shed light on some basic characteristics of oral traditions of the Later Golden Horde. Additionally, this paper will provide information on Tolu Bay, an important, but little known figure in Bärdi Bäk khan’s court.

\footnotetext{
1 On the author and his work consult Bartol'd 1973: 164; Togan 1981: 147-148; DeWeese 1994: 142; Kawaguchi and Nagamine 2010: 47-48; Kafalı 2009: 20-25; Mirgaleev 2011; Ötämiš Hāǰ̌̀̄i/Mirgaleev 2017: 6.

2 There is an unfolding scholarly debate about the character of Ötämiš Hăjyî̀s work. While some scholars view the Čingiz-nāmä as a collection of authentic steppe tradition (Bartol'd 1973: 166; Togan 1981²: 148; Yudin et al. 1992: 25; DeWeese 1994: 142; Kawaguchi and Nagamine 2010: 48-50) others regard it as a compilation of earlier written

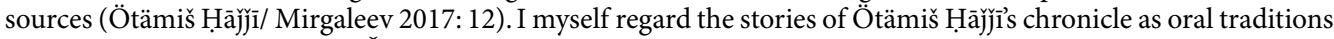
influenced by the author's pro-Šaybānid sympathies.
} 


\section{ÖTÄMIŠ HẬ̃̃̃JI'S STORY OF BÄRDI BÄK KHAN}

The story of Bärdi Bäk khan in the Čingiz-nāmä unfolds as follows: ${ }^{3}$

The beginning of Bärdi Bäk khan’s story: [J̌ānï Bäk khan’s] son, Bärdi Bäk became khan on his father's throne. Bärdi Bäk was a severely mindless and ill-judged person. Claiming that 'The power (hānliq) belongs to me!' he killed his own brothers and his own sons. They say there was a man by the name of Qangli Tolu Bay, whose brothers and tribe were extremely powerful. [He] was the tutor (ataligi) of the khan. Whatever he said, [the khan never] neglected his word. He (i. e. Tolu Bay - Cs. G.) had a son, Sumay by name, a brave archer. In the time of J̄ānï Bäk khan, he committed roguery, and because of this the khan - May mercy be upon him! - had him killed. Tolu Bay, because of his grief for his son, gave the [following] advice [to Bärdi Bäk khan]: - Now you are a young man. Your son who was born today grows up tomorrow. Day by day you grow old. He becomes a young man and tomorrow, after you become old, he claims your power (hānlïg̈ing) [and] takes it. Kill them now! When you start to grow old, then leave one [of them] alive!' he said. This ill-fated took his advice and killed [them all]. Because of this, they call him 'Kötän $n^{4}$ khan who wiped out his root.' In his reign the discord (täfrīqa-lïq) increased greatly. Qiyat Mamay took the right wing, and with the clans (el kün) went to the Crimea. Tengiz Buga, the son of Qïyat Jï Qutli brought the left wing to the Syr Darya river. The khan with his entourage (ički) stayed in Saray. He ruled in Saray for three years, [and] died after. ${ }^{5}$

As it can be seen, the historical consciousness of the Golden Horde preserved the memory of the dissolution of the line of Batu and its connection with the reign of Bärdi Bäk khan. Further, it also recorded that a certain Tolu Bay was the mastermind behind the event, and it explains his actions as an act of revenge. This is basically the variant of 'how the people thought it had happened. But what do other sources, Persian and Russian have to say about him and his role in Bärdi Bäk khan's actions?

\section{HISTORICAL DATA ON TOLU BAY}

First of all, we have to accept that Tolu Bay was a historical figure, his name appears in Turkic chronicles as Tolu Bay (Ötämiš Ḥājj̄ì) and Tolï Bay ('Abdu l-Ǵaffār Qïrïmī), in the Persian sources

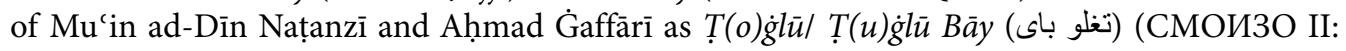
128-129; 211; 233-234; 267), in Russian annals as Товлубій (ПСРЛ I: 228; ПСРЛ IV.: 55, 63; ПСРЛ VIII.: 10; ПСРЛ ХV.: 420) Тавлубій (ПСРЛ Х.: 211), Товлубіи (ПСРЛ ХVIII.: 93), Тувлуби (ПСРЛ ХХІІІ.: 105), Товлубьевом in dative case (ПСРЛ ХХІІІ.: 112), and in a charter preserved in the Venetian dialect as Tolobei and Tolobey (Grigor'ev and Grigor'ev 2002: 147, 160). All these

3 Though there are a number of editions of the Čingiz-nāmä, there is no critical edition of it. By utilising the facsimiles of the Tashkent (Ötämiš Hāăjj̄i/Yudin et al. 1992) and Istanbul (Ötämiš Hāăjj̄i/Mirgaleev 2017) editions, I prepared a critical text with philological remarks on Bärdi Bäk khans reign, given in the appendix. The translation in this section follows the Tashkent manuscript, for alterations, consult the critical text.

${ }^{4}$ The meaning of the word kötän 'bottom, ass' (Rásonyi and Baski 2007: 384), in this context it must have been a derogatory name given to the khan.

${ }^{5}$ The same story is told by the 18th century Crimean historian 'Abdu l-Ġaffār Qïrïmī in his 'Umdetü l-ahbār 'Esence of histories' (Esad ef. 2331, fol. 264v-265r, 'Abdu 1-Ġaffār/Derin Pašaoglu 2014: 77-78). Since 'Abdu 1-Gaffär had access to the Čingiz-nāmä itself, or they have a common source (Kawaguchi and Nagamine 2010: 50), here I restrict my research only on Ötämiš Hāàjìis work. 
variants go back to the same name and mirror regular sound changes in Kipchak Turkic languages. ${ }^{6}$ According to the Onomasticon Turcicum of Rásonyi and Baski, the name Tolu/Tulu was frequently used with the honorary title bay'wealthy' (2007 II: 775-776), thus we have to treat Tolu Bay as the original form of the name. The bey/biy/bi forms of the Russian sources can be considered as misunderstanding of the far more frequent Turkic dignity of a beg/bey/biy. But who was Tolu Bay and why does oral tradition connect him to Bärdi Bäk khan’s fratricide?

\section{TOLU BAY'S ROLE IN BÄRDI BÄK KHAN'S ACCESSION TO THE THRONE}

In the fall of 1356 J̌ānï Bäk khan invaded and seized Azerbaijan, installed his son Bärdi Bäk as governor (hākim) and left for Sarāy. The khan fell ill already during the campaign or shortly after arriving in Sarāy (Safargaliev 1960: 107-108; Gračyov 2011: 50-58). What happened next is summed up in great detail in the chronicle of Mu in ad-Dìn Națanzī. Tog̀lū Bāy, 'a pillar of the state’ of J̌ānï Bäk khan - as Națanzī refers to him - sent a message to Bärdi Bäk about his father’s illness, and called him to Sarāy. However, the khan's health improved. He learnt of the arrival of his son, and this made him suspicious. He consulted the matter with his wife Tigàa Tọ the mother of Bärdi Bäk and with Togglū Bāy, 'unaware that he was the wind of this malice' as Națanzī eloquently writes. Both Ṭogāy Ṭog̀lū hātūn and Tog̉lū Bāy denied Bärdi Bäk’s arrival. Not much later Tog̉lū Bāy, together with some of his men killed J̄ānï Bäk khan and everyone who did not submit to their will. The conspirators then installed Bärdi Bäk as khan. He, in turn, supposed to have said the following to Togilū Bāy: 'I will kill the whole of the kin (urüg) ), just as you killed Muqsān qaraj̄ù. Tog̀lū Bāy - we are told - approved these words. He gathered all the princes, and [Bärdi] Bäk suddenly killed all of them.' He is even supposed to have murdered his 6 months old brother himself (Tizengausen 1941.II.: 128-129; 233-234).

Among the specialists of the Golden Horde Națanzì is regarded as an untrustworthy source (Schamiloglu 1986: 165-170; Sabitov 2010: 151, 154), but in this case his data is unanimously corroborated by a number of Russian annals. The Patriaršaya/Nikonovskaya letopis' also describe the events in details. According to them Tovlubij, a wise and evil temnik (тёмник), i. e. leader of a military contingent of ten thousand men, wanting to rule all the land, persuaded Bärdi Bäk to kill his father and take his throne. He gathered supporters from the tribal aristocracy (князь) to his cause. Bärdi Bäk, together with tribal leaders suffocated the khan and killed twelve of his brothers

\footnotetext{
6 The word derives from the East Old Turkic tuglig 'having ... standard(s)' (ED: 469) and it is formed from the base $t u \dot{g}$ 'a royal emblem' (ED: 464, Doerfer 1965 II: 618-622) and the suffix $+l U G$ forming adjectives (Eckmann 1966: 56-57; Bodrogligeti 2001: 102-104). Different forms of the name mirror stages of sound changes in Kipchak languages, namely the labialisation of word-end $\dot{g}: \dot{g}>w>\emptyset$ (Johanson 1998: 100). The oldest forms of the name appear interestingly in the 15-16th century Persian chronicles: $t(u) \dot{g} l \bar{u}$ or $t(o) \dot{g} l \bar{u}$, with the final $\dot{g}$ preserved in $t u \dot{g}$ (but interestingly not on the suffix!). This would mean that Mu'īn ad-Dīn Națanzī and Gaffārī utilised sources/ traditions in which these sound shifts did not came to pass. In the $14^{\text {th }}$ century monument of the Kipchak language, the Codex Cumanicus the word appears as tov'insegnia', t. i. insignia (Grønbech 1942: 250), this corresponds to the forms of the Russian annals Товлубій, Тавлубій, etc. where we encounter the already labialised form. The variant of Ötämiš Hājj̄̄i (Tolu Bay) and 'Abdu l-Gaffār (Tolï Bay) represent therefor the newest forms, as can be seen in a number of modern Kipchak languages: Kirgiz: tuи 'знамя, стяг' and tииlии 'со знаменем, со стягом' (Yudahin 1965: 771-772), Kazakh tu'standard, banner' (Shitnikov 1966: 205).

7 Ṭogāy Ṭog̉lū hātūn is certainly the wife of Özbäk khan, mother of J̌ānï Bäk khan and grandmother of Bärdi Bäk khan, Tajdula in Russian annals. On her name and variants see Pelliot 1949: 101-105.
} 
(ПСРЛ Х.: 229). ${ }^{8}$ Even if the description differs in some minor details, they clearly state that Bärdi Bäk seized the throne by a conspiracy and Tolu Bay was on the forefront of the events. This variant of the story - as the sources are earlier, unconnected and unanimous - can be regarded as the 'how it must have happened'.

\section{FURTHER REFERENCES ON TOLU BAY}

Russian chronicles contain a range of additional data on Tolu Bay and his carrier. ${ }^{9}$ By scrutinizing these we may verify some of Ötämiš Hājyjìs details on Tolu Bay on the one hand, and gain insight into the carrier of Tolu Bay on the other.

In 1339 Özbäk khan summoned the prince of Tver, Aleksandr Mihajlovič (1301-1339). He was charged with organising a plot against Tatar rule in the Rus' principalities and was eventually killed by the men of the khan. ${ }^{10}$ Among them the author of the Terskoj sbornik mentions Tovlubij who headed the execution (ПСРЛ ХV.: 420). Later that year a number of Russian annals report on a joint Tatar-Rus' punitive expedition against the town of Smolensk, whose prince refused to pay their taxes. On the head of the troops the sources mention a 'mighty envoy' (посоль), Tovlubij (ПСРЛ Х.: 211; ПСРЛ ХV.: 424;). It is safe to assume that the Tovlubij of Alexandr Mihajlovičs execution and the 'envoy' leading the forces against Smolensk are one and the same. In any case it is clear that this Tovlubij was not just an executioner and an 'envoy', but also a high ranking member of the military organisation of the Golden Horde, having a considerable number of Tatar and tributary troops at his disposal. ${ }^{11}$

For the next two decades there is no information on Tolu Bay neither in Russian, nor in Persian sources. He reappears only in connection to the plot against Jānï Bäk khan. The charters of the Golden Horde khans usually mention the highest dignitaries of the state organisation. Since neither the charters of Özbäk, nor J̄ānï Bäk khan list his name, Safargaliev came to the conclusion that Tolu Bay must have been an 'ämīr of second grade' (Safargaliev 1960: 109) which seems reasonable, with the remark that he was influential enough to initiate a successful coup d'etat. ${ }^{12}$ At the time of the plot, he must have been a higher dignitary of the military organisation, since Gaffārī calls him as an amīri-i laškar 'commander of the army' (Tizengausen 1941.II.: 211, 267). Russian sources corroborate the Persian data, where he appears - as mentioned above - temnik (ПСРЛ X.: 229), i. e. Turkic tümen begi 'leader of ten thousand men'. This piece of information - in my view - affirms the assumption, that Tolu Bay, the 'envoy' sent to Smolensk in 1339 and Tolu Bay of the coup d'état are one and the same person.

According to Ötämiš Hājȳjī, Tolu Bay could exercise power over Bärdi Bäk khan due to the khan's 'mindlessness' and 'ill-judgement' ( $b \bar{\imath}$ - 'aql wä bì-mulāhaza kiši erdi), and to the fact that he was the tutor (ataliq) of the khan (Ötämiš Hāǎǰi/Kawaguchi and Nagamine 2008: 31, 87-88).

\footnotetext{
8 See further ПСРЛ ІV.: 63.

9 References on Tolu Bay in Russian and Persian sources are given in the work of Seleznyov 2009: 177-178.

${ }_{10}$ For an overview of the event and further literature on them see Hautala 2017: 471-474.

11 Although the Nikonovskaya or Patriaršaya letopis' also mention a certain Mengukaš together with Tolu Bay, the command of the troops seems to have been assigned to the later (Seleznyov 2009: 128-129).

12 Safargaliev (1960: 109) claims that Tolu Bay remained in the capital and started the organisation of the plot already during J̌ānï Bäk khan's campaign against Azerbaijan. Though his claim seems reasonable, there are no sources supporting it.
} 
Russian annals also suggest a certain form of tutorship to Tolu Bay. He is either called an učitel' (учитель) 'tutor' on the one hand (ПСРЛ Х.: 229), and predstatel' (предстатель), an archaic Russian word for 'protector, patron' on the other (ПСРЛ V.: 228; ПСРЛ VIII.: 10; ПСРЛ ХХІІІ.: 112). It seems that in this instance the oral tradition preserved trustworthy details of Tolu Bay.

If we take a closer look at some sources describing the execution of Alexandr Mihajlovič, we can raise serious questions about the tribal affiliation of Tolu Bay. As cited above, Ötämiš Hājyji thought him to come from the tribe Qanglï, a statement which was accepted by scholars as Isxakov (2009: 51) and Sabitov (2014: 130). For an unknown reason, the Grigor'evs without any ground thought him to be a leader of the Bagrïn tribe (Grigor'ev and Grigor'ev 2002: 125; Grigor'ev 2004: 87). The author of the $16^{\text {th }}$ century Tverskoj Sbornik, however, mentions Tolu Bay as a Cherkes: 'Prince Aleksandr raised his eyes, ordered the fifth prayer (nemu yacbl), his final prayer [to be sung]; he raised his eyes and saw the Čerkes heading to his tent, Tatars with him who ran him over. They mercilessly grappled him, wrestled him, tore down his clothes, placed him before Tovlubij naked and tied up. And he [Tovlubij - Cs. G.], the infidel sitting on a horse, surrounded by numerous Tatars, made his damned voice be heard: Kill him! And they grabbed prince Aleksandr and his son, prince Feodor, they stabbed them mercilessly, laid them on the ground, cut their heads of; and thus they met their end, excepted such fait for the Christian nation' (ПСРЛ ХV.: 420). ${ }^{13}$ The Patriaršaya/Nikonovskaya letopis' mention two persons at the execution of the prince, a certain 'Berkan' and 'Čerkas' (ПСРЛ Х.: 210). Keeping the entry of the Tverskoj sbornik in mind, it is safe to assume that the later refers to Tolu Bay. We already saw that Ötämiš Hājȳi and some Russian annals call Tolu Bay as the tutor (ataliq, учитель, предстатель) of Bärdi Bäk khan. We know little of the atalïgs of the Golden Horde, but in the period of the Later Golden Horde the princes of the Crimean and Kazan' Khanats, even the sons of the Nogay biys were raised among the Cherkes of the Caucasus (Belyakov, Vinogradov and Moiseev 2007: 413). This practice might as well go back to the Golden Horde period. The $17^{\text {th }}$ century compilation of oral traditions of the Volga area, another Čingiz-nāmä also connects the youth of Bärdi Bäk khan to the Cherkes (Ivanics and Usmanov 2011: 83; Ivanics 2017: 252). In my view all this points out that we should link Tolu Bay to the Cherkes, and not to the Qangli. Be it as it may, this peace of data about the origin of Tolu Bay in the Čingiz-nāmä of Ötämiš Hāăjȳi should be treated with caution.

It was already mentioned that before the plot against J̌ānï Bäk khan the name of Tolu Bay did not appear on Golden Horde charters, which means that he was not among the highest members of the state organisation, the so called four ulus begs. According to the charter of Bärdi Bäk khan given to the Venetians in 1358, the number of the ulus begs rose to six, and Tolu Bay was listed fifth among them (Grigor'ev and Grigor'ev 2002: 160). This means that the dignity and power of Tolu Bay rose, undeniably his support to the khan had a major role in this. It is safe to assume that contrary to his fifth place in the charter, he became a leading figure after the khan (Safargaliev 1960: 110), maybe a sort of eminence grise. The same charter also testifies that Tolu Bay was rewarded with a share of the customs in Azov (Grigor'ev and Grigor'ev 2002: 148, 152).

${ }_{13}$ Князь же Александрь взведе очи свои, повеле пети часы; се же им кончавшим часы, и взведе очи свои, и видевь Черкас, идуще прямо к веже своей, и с ним Татарове, и выскочи противу его. Они же немилостивый похватиша его, взложи(ша) назад, и оборваша порты его, и поставиша и перед Товлубием нага связана. Ономуже безаконному стоашу на коне, и с ним множество Татар, испусти окаанный глас свой: “убийте.» Они же емше князя Александа и сына его князя Феодора, без милости прободоша, и поврьгоша на земли, отсекоша главы им; и тако скончашася, и приемше таковую кончину за род христианьский. 
In the short reign of Bärdi Bäk khan his power - according to all sources - deteriorated. Ötemiš Hâjjyi states that the clans of the Golden Horde migrated to the Crimea and to the vicinity of the Syr Darya under the rule of clan leaders, Mamay and Tengiz Buga. The khan on the other hand remained in the capital Sarāy, only with his entourage (ički), where he died of sickness. To the contrary of Ötemiš Hājȳīs narrative Russian sources tell a different story. They mention a certain Kulpa, who challenged the rule of the khan. Ironically, Kulpa - according to the study of Grigor'ev (1983: 22-26) - managed to take Azov, zone of interest of Tolu Bay, and minted his coins already in 1358. Though sources - both written and numismatic - for these events are scarce, it is clear that Kulpa took the capital next year, overthrew and killed Bärdi Bäk. The Patriaršaya/ Nikonovskaya letopis' portrays these events vividly under the year 1359: 'In the summer of the same year, car' Berdibek, son of Čyanibek, grandson of Azbyak, was killed in the Horde; and with [his] his well-wisher, the wretched Tolubiy, an evil and powerful knyaz', and other counsellors of his [he] drank out the same cup that he filled for his father and brother[s]' (ПСРЛ Х.: 230-231). ${ }^{14}$ The mere fact that the annals mention only Tolu Bay by name points out his might and influence in the affairs of the Golden Horde. Since numismatic finds corroborate the details of our Russian sources, we have every reason to give credit to them.

\section{CONCLUSIONS}

When we compare the evidence of Persian and Russian sources to Ötämiš Hāǎjū̉s plot of Bärdi Bäk khan, it becomes clear that the historical consciousness erased the memory of the plot against J̄ānï Bäk khan, it kept only the dissolution of the Batuid line and its connection to Tolu Bay. In an interesting manner, it also recorded the fact that he was the tutor of the khan. So the plot had a deed, a villain, it required only a motive for Tolu Bay. Thus, the historical consciousness constructed one, namely that Tolu Bay was acting because of personal motives, trying to avenge his son. We might even consider this phenomenon as a feature of steppe historiography. It operates with historical events and persons, it even preserves trustworthy details of some individuals, but at the same time it deploys fictional elements, motives to explain a plot. From this analysis we can conclude that the Čingiz-nāmä of Ötämiš Hājȳji is a valuable asset for the study of the Golden Horde, but the traditions it preserved could change considerably. Every detail of the chronicle must be approached with criticism and at the same time it is of paramount importance to corroborate it with other sources or group of sources.

\section{APPENDIX}

In the following I give a critical text of Bärdi Bäk khan's reign from the Čingis-nāmä. The facsimile of the Tashkent manuscript (ÖHt) - published in Yudin et al. 1992 - serves as the principal text which is supplemented by the one in Istanbul (ÖHi) - published by Mirgaleev 2017. Words, suffixes etc. absent in the ÖHt but present in the ÖHi are given in (round brackets), unreadable

\footnotetext{
14 Того же лета во Орде убиен бысть изарь Бердибек, сын Чянибеков, внук Азбяков, и з доброхотом своим окаанным Товлубием, князем темным и силным, и со иными советники его; и испи тую же чашу, еюже напоил отиза своего и братью свою.
} 
words with (---), interpolations in [square brackets]. Different wordings of the ÖHi are given in footnotes. Since the remarks on the margin of the ÖHi seems to originate from a version of the ÖHt, I leave them from the critical text.

Editions utilised are ÖHt/ Yudin et al. 1992: 135; ÖHt/Kawaguchi and Nagamine 2008: 31-32; 87-88; ÖHi/Kafalı 2009: 128; ÖHi/Mirgaleev 2017: 239-240, 221.

āgāa-i dastān-i Bärdi Bäk hāan ${ }^{15}$ og̀lï Bärdi Bäk (hān) atasï tahtïnda ${ }^{16}$ hān boldï Bärdi Bäk ${ }^{17}$ bäsīi ${ }^{18}$ bī- 'aql wä bī-mulāḥaża ${ }^{19}$ kiši erdi özining qarïndašlarï ${ }^{20}$ taqï öz og̉lanlarïnï manga hānlïq talašur deb ${ }^{21}$ öltürür erdi ayturlar Qanglï Tolu Bay tegän qawmï qarïndaš[ï] köb küjlük kiši erdi bu hānnïng atalïgï erdi här nä aytsa ${ }^{22}$ anïng sözindin čiqumaz ${ }^{23}$ erdi anïng bir oglii bar erdi Șumay $^{24}$ atlïg alp ${ }^{25}$ atgučì erdi ol Șumay ${ }^{26}$ (hażrät-i) J̌ānï Bäk hān zamānïnda qaraqčilïq ${ }^{27}$ qïlur erdi anïng ǰihätidin ${ }^{28}$ hān 'aläyhi r-raḥmät anï öltürüb erdi Tolu Bay ol ${ }^{29}$ og̉lïnïng aỷigïïin bu kängäšni ol berür aytur ${ }^{30}$ erdi sen hāalā ${ }^{31}$ yigit turur-sen ${ }^{32}$ bu mahall-daqii ${ }^{33}$ togggan og̉lïng tang ösär ${ }^{34}$ sen kündin küngä qarïr-sen ol yigit bolur(lar) tangla sen qarïgandïn song hānlïgïng-nï talašïb ${ }^{35}$ alg̀ay ḥālā bular-nï öltürä (---) tur-gïil qačan qarï bašlasang andïn song ${ }^{36}$ (biräwni) qoygay-sen ter edi (sic!) ol bì-däwlät häm munung ${ }^{37}$ sözigä kirib öltürür erdi bu säbäbdin anga kögin ${ }^{38}$ (qïrg̉an) kötän hān terlär anïng zamānïnda täfrīqa-lïq bisyār boldï ong qolnï Qïyat ${ }^{39}$ Mamay alïp el kün

15 ÖHi: missing.

16 ÖHi: yerindä

17 ÖHi: $b u$

18 ÖHi: bäs

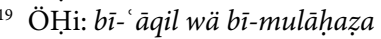

20 ÖHi: qarïndašlarïnï

21 ÖHi: teb

22 ÖHi: ol här nä aysa

23 ÖHi: aṣlan täjāwüz qülmas

24 ÖHi: Șumari

25 ÖHi: alip

26 ÖHi: missing.

27 ÖHi: qaraqčulïq

28 ÖHi: ol jihätdin

29 ÖHi: $m a ̈ z k \bar{u} r$

30 ÖHi: ol berä (?) aydï

31 ÖHi: missing.

32 ÖHi: yigit-durur-sen

33 ÖHi: mahall-daq $і$

${ }^{34}$ ÖḤi: og̉lanlarïnïng birlä tang öšärsin

35 ÖHi: tiläšib (?)

36 ÖHi: missing.

37 ÖHI: munïng

38 The Tashkent manuscript has the form كركين, thus its editors read keräkin (Ötämiš Hāǎj)î/Kawaguchi and Nagamine 2008: 89) and kärkin (Ötämiš Hājūî/Yudin et al. 1992: 135). Although the manuscript supports this reading - the word kärkin is documented in Teleut 'ein großer Dolch' (Radloff $1960^{2}$ II.: 1100) - I would suggest that the scribe copying the manuscript made a lapsus calami. The wording in Istanbul manuscript, which has kögin qürgan 'the one who wiped out his roots', fits the fratricidal actions of Bärdi Bäk khan better. A similar phrase (kögin uyu-gan kötän hān) on Bärdi Bäk khan can be found in a manuscript of the $17^{\text {th }}$ century Čingiz-nämä of the Volga region, see Mustakimov 2009: 123.

39 ÖHi: Written erroneously as قيالى. The correct should be Qïyat. 
birlä ${ }^{40}$ Qïrïm-ġa kitdi sol qolnï (50b) Qïyat J̌ir Qutlï og̉lï ${ }^{41}$ Tengiz Bug̉a Sīr däryāsï boynïga ${ }^{42}$ alïp kitdi hān öz(i) ički(si) birlä(n) Sarāyda boldï ${ }^{43}$ üč yïl Sarāy šähindä pādišāh boldï ${ }^{44}$ andïn song wäfāt boldï ${ }^{45}$

\section{ABBREVIATIONS}

$\mathrm{ED}=$ Clauson 1972.

ПСРЛ = Польное собрание русских летописей.

$\mathrm{ZC}[3 ц]=$ Mirgaleev 2008.

\section{REFERENCES}

'Abu l-Ġaffār Qïrïmī (n. d.) 'Umdetü l-ahbār. MS in: Süleymaniye Yazma Eserler Kütüphanesi Instanbul, Esad ef. 2331.

BARTol’D, Vasilij Vladimirovič [Бартольд, Василий Владимирович] 1973. ‘Отчет о коммандировке в Туркестан’ In: Бартольд, Василий Владимирович Сочинения VIII. Москва: Наука, 119-210.

Belyakov, Andrej Vasil'evič, Aleksandr Vadimovič Vinogradov and Maksim Vladimirovič Moiseev [Беляков, Андрей Васильевич и Виноградов, Александр Вадимович и Моисеев, Максим Владимирович] 2017. 'Институт аталичества в постзолотоордынском мире.' Золотоордынское обозрение 5/2: 412-436.

Bodrogligeti, András, J. E. 2001. A Grammar of Chagatay. [Languages of the Word/Materials 155] Muenchen: Lincom Europa.

Clauson, Gerard 1972. An Etymological Dictionary of Pre-Thirtheen-Century Turkish. Oxford: Clarendon Press.

Eckmann, János 1966. Chagatay Manual. [Indiana University Publications, Uralic and Altaic Series 60.] The Hague: Mounton and Co.

Derin Pašaoglu, Derya [Дерин Пашаоглу, Деря] 2014. Абдулгафбар Кырыми: Умдет ал-ахбар. [Серия «Язма мирас. Письменное наследие. Textual Heritage.» Выпуск 1] Казань: Институт истории им. Ш. Марджани АН РТ.

Desmaisons, Petr I. $1970^{2}$. Histoire des Mongols et des Tatars par Aboul-Ghâzi Béhâdour Khân. Amsterdam: Philo Press.

DeWeese, Devin A. 1994. Islamization and Native Religion in the Golden Horde. Baba Tükles and Conversion to Islam in Historical and Epic Tradition. [Hermeneutics: Studies in the History of Religion] Pennsylvania: Pennsylvania State University Press.

Doerfer, Gerhard 1963-1975. Türkische und mongolische Elemente im Neupersischen. 4 Vols. Wiesbaden: Franz Steiner Verlag.

\footnotetext{
40 ÖHi: missing.

${ }^{41}$ ÖHi: missing.

${ }^{42}$ ÖHi: $b . w . y . k \cdot \bar{a}(?)$

43 ÖHi: bolur edi

${ }^{44}$ ÖHi: pādišāh-lïq qüldï

${ }^{45}$ ÖHi: tapdï
} 
Gračyov, Anton Igorevič [Грачёв, Антон Игоревич] 2011. 'Поход хана Джанибека в Иран в 1356-1357 гг. Анализ и реконструкция хронологии собитий.' In: 3u Выпуск 4: 47-58.

Grigor'ev, Arkadij Petrovič [Григорьев, Аркадий Петрович] 1983.'Золотоордынские ханы 60-70-х годов XIV в.: хронология правлений. Историография и источниковедение истории стран Азии и Африки Выпуск 7.9-54.

Grigor'ev, Arkadij Petrovič [Григорьев, Аркадий Петрович] 2004. Сборник ханских ярликов русским митрополитам. Историковедческий анализ золотоордынских документов. Санкт-Петербург: Издательство санкт-петербургского университета.

Grigor'ev, Arkadij Petrovič and Grigor'ev, Vadim Pavlovič. [Григорьев, Аркадий Петрович и Вадим Павлович] 2002. Коллекиия золотоордынских документов ХIV века из Венеции. Историческое исследование. Санкт-Петербург: Издательство санкт-петербургскога университета.

Grønbech, Kare 1942. Komanisches Wörterbuch. Türkischer Wortindex zu Codex Cumanicus. [Monumenta Linguarum Asiæ Maioris Subsidia I.] København, Einar Munksgaard.

Hautala, Roman 2017. 'Russian Chronicles on the Religious Policy of Uzbek Khan (1313-1341) and his Relations with the Principalities of the North-Eastern Rus.' In: Hautala, Roman 2017. Crusaders, Missionaries and Eurasian Nomads in the $13^{\text {th }}-14^{\text {th }}$ Centuries: a Century of Interactions. Ed. by.: SPINEI, Victor. [Florilegium magistrorum historiae archeologiaeque Antiquitatis et Medii Aevi XXI.] Bucureşti - Brăila: Editura Academiei Române - Editura Istros a Muzeul Brăilei „Carol I”. 455-477.

Isнakov, Damir Mavyaveevič [Исхаков, Дамир Мавявеевич] 2009. Исторические очерки. [Biblioteka Tatarica] Казань: Фэн.

Ivanics, Mária and Usmanov, Mikrasym Abdulahatovič 2002. Das Buch der Dschingis-Legende (Däftär-i Čingiz-nāmä) I. [Studia uralo-altaica 44.] Szeged: Quality Print.

Ivanics, Mária 2017. Hatalomgyakorlás a steppén. [Magyar Történelmi Emlékek Értekezések] Budapest: MTA BTK Történettudományi Intézet.

Johanson, Lars 1998. 'The History of Turkic.' In: Lars Johanson and Éva Á. Csató (eds.) The Turkic Languages. London - New York: Routledge: 81-125.

Kafalı, Mustafa 2009. Ötemiş Haciya göre Cuci ulusu’nun tarihi. [Türk Tarihi Araştırma Enstitüsü Yayınları] Ankara: Öncü Basımevi.

KawaGUChI, Takushi 川口玩司 and Hiroyuki Nagamine 長峰博之 2008. ウテミシュ・ハージ: チンギ ズ・ナーマ.Ötämiš Hājī: Čingiz-nāma. [Studia Culturae Islamicae No.94] Tokyo: Fujiwara Printing Co.

Kawaguchi, Takushi and Nagamine, Hiroyuki [Кавагучи, Такуши и Нагаминэ, Хироюки] 2010. 'Некоторые новые данные о «Чингиз-наме» Утемиша-хаджи: в системе историографии в Дашт-и Кипчаке.' Зи Выпуск 3: 44-52.

Mirgaleev, Il'nur Midhatovič [Миргалеев, Ильнур Мидхатович] (ред.) 2008. Золотоордынская изивилизация. Сборник статьей. Казань: Институт истории им. Ш. Марджани АН РТ.

Mirgaleev, Il'nur Midhatovič [Миргалеев, Ильнур Мидхатович] 2011. “Чингиз-наме» Утемиша хаджи: перспективы изучения.' In: 3u Выпуск 3: 14-19.

Mirgaleev, Il'nur Midhatovič [Миргалеев, Ильнур Мидхатович] 2017. Утемиш Хаджи: Кара таварих. [Серия «Язма мирас. Письменное наследие. Textual Heritage. » Выпуск 4] Казань: Институт истории им. Ш. Марджани АН РТ.

Mustakimov, Il'yas Al'fredovič [Мустакимов, Ильяс Альфредович] 2009. ‘Об одном списке «Дафтар-и Чингиз-наме». In: Хакимов, Рафаиль Сибгатович (ред.) Средневековые тюрко-татарские государства. Сборник статей. Выпуск 1. Казань: Институт истории Ш. Марджани АН РТ. 122-131.

Pelliot, Paul 1949: Notes sur l'histoire de la Horde d'Or: suivies de qelques nom turcs d'hommes et de peoples finissant en "ar". [Oeuvres posthumes de Paul Pelliot 2] Paris: Libr. d'Amérique et d'Orient. 
Польное собрание русских летописей I 1846. Лаврентевская и Троицкая летописи. Санктпетербург: Типография Эдуарда Праца.

Польное собрание русских летописей IV 1848. Новгородския и Псковския летописи. Санктпетербург: Типография Эдуарда Праца.

Польное собрание русских летописей V 1851. Псковския и Софийския летописи. Санктпетербург: Типография Эдуарда Праца.

Польное собрание русских летописей VIII 1859. Продолжение летописи по Воскресенскому списку. Санктпетербург: Типография Эдуарда Праца.

Польное собрание русских летописей X 1885. Летописный сборник, именуемый Патриарщею или Никоновскою летописью. Санктпетербург: Типография министерства внутренных дел.

Польное собрание русских летописей XV 1863. Летописьный сборник, именуемый Тверскою летописью. Санктпетербург: Типография Леонида Демиса.

Польное собрание русских летописей XVIII 1913. Симеоновская летопись. Санктпетербург: Типография М. А. Александрова.

Польное собрание русских летописей XXIII 1910. Ермолинская летопись. Санктпетербург: Типография М. А. Александрова.

Radloff, Friedrich Wilhelm $1960^{2}$. Versuch eines Wörterbuches der Türk-Dialekte. 4 Vols. The Hauge - Rijswijk: Mouton \& Co. - Krips Repro.

RÁsonyi, László and BAski, Imre 2007. Onomasticon Turcicum. Turkic Personal Names as collected by László Rásonyi. 2 Vols. [Indiana University Uralic and Altaic Series] Bloomington: Indiana University, Denis Sinor Institute for Inner Asian Studies.

SABitov, Žaksylyk Muratovič [Сабитов, Жаксылык Муратович] 2010. 'Натанзи как источник по истории Золотой орды' In: Зи Выпуск 3: 150-155.

SABItov, Žaksylyk Muratovič [Сабитов, Жаксылык Муратович] 2014. Ээмиры Узбек-хана и Джанибекхана' Золотоордынское обозрение 2/4: 120-134.

Safargaliev, Magmet Garifovič [Сафаргалиев, Магмет Гарифович] 1960. Распад Золотой орды. Саранск: Мордовское книжное издательство.

Schamiloglu, Uli 1986. Tribal Politics and Social Organization in the Golden Horde. Columbia University: unpublished $\mathrm{PhD}$ dissertation.

Seleznyov, Yurij Vasil'evič [Селезнёв, Юрий Васильевич] 2009. Элита Золотоы орды. Казань: Фэн.

Sнiтnікоv, Boris Nikolajevich. 1966. Kazakh-English Dictionary. London - The Hague - Paris: Mouton \& Co.

Tizengausen, Vladimir Gustavovič [Тизенгаузен, Владимир Густавович] 1941. Сборник материалов относящихся к истории Золотой орды II. Извлечения из персидских сочинений. МоскваЛенинград: Издательство академии науик СССР.

TogAN, Ahmed Zeki Velidi $1981^{2}$. Bugünkü Türkili (Türkistan) ve yakın tarihi. Cilt I. Batı ve kuzey Türkistan. İstanbul: Enderun Kitabevi.

Yudaxin, Konstantin Kuz’mič [Юдахин, Константин Кузьмич] 1956. Киргизко-русский словарь. Москва: Издательство «Советская энциклопедия».

Yudin, Veniamin Petrovič et al. [Юдин, Вениамин Петрович et al.] 1992. Утемиш-хаджи: Чингиз-наме. Алма-ата: Гылым.

Open Access. This is an open-access article distributed under the terms of the Creative Commons Attribution 4.0 International License (https://creativecommons.org/licenses/by/4.0), which permits unrestricted use, distribution, and reproduction in any medium, provided the original author and source are credited, a link to the CC License is provided, and changes - if any - are indicated. (SID_1) 